\section{UK release of four genetically manipulated organisms planned}

\section{London}

Potatoes are likely to be the first genetically engineered plants to be grown in field trials in Britain. Two proposals for planting in May or June have been made to the UK watchdog on deliberate release experiments, the Advisory Committee on Genetic Manipulation (ACGM). But both have run into some problems which will need to be resolved by the next ACGM meeting, in mid-May, for optimal plantings this year. The same meeting may also be the last chance for two other releases, one of bacteria and the other of viruses, to go ahead this year.

Only two of the proposals involve organisms that have been produced by genetic engineering in the sense of using recombinant DNA technology to alter their genetic make-up. One is a potato experiment proposed by the Plant Breeding Institute in Cambridge; the other is the second phase of a project planned by the Institute of Virology in Oxford. The organisms involved in the other two experiments have been produced at Rothamsted Experimental Station by more classical means of genetic manipulation which have nonetheless been deemed to fall within the purview of ACGM, somewhat to the initial surprise of the investigators.

The ultimate aim of the Cambridge work is to produce disease resistance and, perhaps, increased protein in potatoes, but the initial trial is only of a prototype containing convenient, rather than useful, genes. One gene confers antibiotic resistance on the plant cells, which has allowed their selection in the laboratory. The other gene encodes a bacterial enzyme that can easily be assayed.

Plants with both genes have been obtained by tissue culture and tested in glasshouses. The plan now is to grow about 2,000 of them in a small plot this year and then to replant the tubers next year, which will provide a better measure of any effects of the genes on the yield and size of the potatoes and the gross morphology of the plants.

Details of the proposed planting were sent last December to ACGM, which responded only in March with several suggestions and an amended plan will be reconsidered in May. A varietıy of precautions are included to prevent any spread of the plants beyond the experimental plot.

Similar precautions have had to be incorporated in the Rothamsted potato experiment even though the plants are the result only of fusions between cells of two species of potato, just one of which is resistant to the leaf roll virus. As hoped, some of the hybrids are also resistant.
The other Rothamsted proposal involves Rhizobium, the nitrogen-fixing bacterium of leguminous plants. The experiment is financed by a European Economic Community programme for risk assessment in biotechnology and has both French and German collaborators. To test the extent of genetic transfer betwen rhizobial species in the soil a Rhizobium has been genetically marked with a DNA transposon from a different bacterial genus and as one of ACGM's concerns is to prevent this kind of genetic transfer, the experiment was bound to be problematic. The original plan is being redrafted in response to considerable, if delayed, criticism by ACGM. Ironically, similar experiments were carried out by a member of ACGM before it came into existence.
Tokyo

THE International Tropical Timber Organization (ITTO), a world body mandated to promote timber trade and preserve tropical forests, began its first council meeting in Yokohama in a state of financial crisis. By the end of the five-day meeting many member countries, including the United States, had failed to pay the dues essential for the secretariat's operations. But Japan, the biggest financier of destruction of the world's tropical forests, came away with a glowing image having pledged by far the largest voluntary contribution to the organization's special project fund.

ITTO was established last summer by all the major tropical timber producing and consuming nations under the International Tropical Timber Trade Agreement, which includes among its principal goals the preservation of tropical forests (see Nature 312, 493; 1986). Japan lobbied hard to host the organization's headquarters, and after a year-long squabble, Yokohama was chosen over Amsterdam, Jakarta and Rio de Janiero.

Some environmentalists expressed concern at the choice of Japan, fearing the host might compromise the organization's conservation objectives: Japan gobbles up nearly half the world's tropical timber trade, much of the imports being wasted on disposable chopsticks $(11,000$ million pairs a year) and panelling for concrete, and vast tracks of forests in South-East Asia have been laid to waste to satisfy Japan's appetite for tropical hardwood.

But at the council meeting, Japan was
The Institute of Virology's experiment is the second phase of a project that started last year with what is, so far, the only deliberate release of genetically engineered organisms in Britain. Last summer, institute scientists released a baculovirus that was genetically marked so that its survival could be monitored. Ultimately the plan is to alter the virus to improve its value as a biological pesticide. Such viruses will also be altered so as to limit their survival and it is one such 'suicide' virus that may be tested this summer.

Although ACGM is a voluntary body that gives advice rather than approval for experiments, none of the experimenters will go ahead this year if the committee is not satisfied with their modified proposals. As ACGM is building up guidelines on a case-by-case basis, delays are not surprising but given the slowness with which ACGM has reacted to most of the outstanding proposals, there will still be a good deal of frustration if any are delayed by a year.

\title{
Japan faces both ways on timber conservation in tropical forests
}

the first to step forward with a handsome contribution of $\$ 2$ million to finance projects on reafforestation, sustainable management and economic/market information gathering. Other nations were slow to respond to the Japanese move. And so a group of environmental organizations, including Friends of the Earth and the World Wildlife Fund, chipped in more than $\$ 12,000$ to try and shame others into action. Switzerland quickly came up with $\$ 1$ million, followed by the Netherlands with $\$ 600,000$. And at the end of the meeting, $\$ 640,000$ was allotted to establish in-house statistical capability, and to do preliminary work on ten potential projects before the council's next meeting in the autumn.

But the projects may never get off the ground because several member nations have failed to pay the membership dues essential for everyday running of the organization. By the end of the meeting on 27 March, nearly $\$ 700,000$ was still owed, $\$ 50,000$ by the United States.

Charles Secrett of Friends of the Earth International, an official observer at the meeting, while welcoming the voluntary contributions from Japan, Switzerland and the Netherlands, condemned the nonpaying member nations. "It is beyond belief that the whole work programme of the ITTO may fail simply because a few selfish countries refuse to pay money they owe. By miserly skimping on the small change, the defaulters are threatening the future of the one international organization that could save the world's tropical forests." David Swinbanks 